\title{
Is the knowledge about the wild birds influenced by the socioeconomic conditions of the human populations?
}

Surane da Silva Nogueira Santos ${ }^{1}$; Cláudia Sofia Guerreiro Martins ${ }^{2}$ and Flávia de Campos Martins ${ }^{3, *}$

\begin{abstract}
The human populations of the Brazilian semiarid region interact strongly with the avifauna throughout the entire occupation of its territory. These interactions were established in a context of adverse edaphoclimatic conditions that limited crop production and socioeconomic welfare, making the uses of birds as food and income frequent excuses to label them as important subsistence resources. It is relevant to know whether such interactions today are still influenced by socioeconomic factors and in what way. Semi-structured questionnaires were applied to 105 residents, 45 men and 60 women, in rural communities of Casa Nova, Bahia state. Correlation analysis and regression models were performed to verify how the socioeconomic variables 'gender', 'age', 'education', 'monthly income' and 'residence time' of respondents explain the variation in the number of known species and the acknowledgement of the ecological importance of the birds. There were 840 bird citations, corresponding to 60 species. A correlation between age, income, residence time in the region and the number of species mentioned arouse, but there was no correlation with the acknowledgement of the ecological importance of the species. Men cited significantly more bird species than women. The results also indicate a low level of knowledge about bird species among younger populations. Socioeconomic factors strongly influence people's knowledge of bird species in their region. Exposure to wild birds and experience with it, gender, education and income together influence the knowledge about the diversity of this group.
\end{abstract}

Keywords: Ethnozoology; Ethno-ornithology; Semiarid; Conservation.

1 Programa de Pós-Graduação em Ciência e Tecnologia Ambiental para o Semiárido (PPGCTAS) UPE, Campus Petrolina, PE, 56328-903, Brazil

2 Núcleo de Ecologia e Monitoramento Ambiental, Universidade Federal do Vale do São Francisco, Campus Ciências Agrárias, BR 407, Km 12, lote 543, Projeto de Irrigação Nilo Coelho, S/N C1, Petrolina, PE, 56300-000, Brazil

3 Colegiado de Ciências Biológicas, Universidade de Pernambuco Campus Petrolina, PE, 56328-903, Brazil

* Corresponding author. $₫ \mathrm{E}$-mail address: SSNS (surane.nogueira@hotmail.com), CSGM (csgmartins@gmail.com) and FCM (flavia.martins@upe.br)

\section{SIGNIFICANCE STATEMENT}

This manuscript is the first scientific contribution relating knowledge about wild birds and its uses by human populations in the region of Casa Nova, Bahia state, Brazil. Furthermore, it brings new insights into how socioeconomic factors impact people's knowledge about birds, predicting important causal relationships for conservation education projects and actions for sustainable development. 


\section{INTRODUCTION}

The way each society interacts with wildlife makes it possible to gather information about species over the years (Alves and Souto 2015). Traditional societies store a vast dynamic and holistic collective ecological knowledge, resulting from historically constructed, socially shared experiences and individual learning (Toledo 2005; Toledo and Barrera-Bassols 2008). Such knowledge is derived from the management needs and impregnated with perceptions, values and beliefs that are transmitted throughout generations and influence the way humans interact with other animals (Drew 2005; Mourão and Nordi 2006). To understand human populations perceptions about natural resources and how management decisions and ecological relations are established is the key to design efficient conservation projects that also reduce poverty and increase people's livelihoods (Tucker 2007).

Among the vertebrates, birds are much appreciated (Soares et al. 2018a) and have been incorporated into human culture throughout history (Bezerra et al. 2012), mainly because they present a set of distinct characteristics of other animals such as colored plumage, capacity to fly and to sing, and for being active and easily seen during the day (Stotz et al. 1996; Alves et al. 2010).

Northeastern Brazil harbors a relative biodiversity of wild birds, with 548 species already recorded (Araujo and Silva 2017). It is also one of the most populated semiarid territories in the planet, home to about 28 million people, mostly rural inhabitants (Silva et al. 2017), with low human development indexes $(\mathrm{HDI})$. In this environment, where the long periods of drought compromise subsistence activities, such as agriculture and livestock, the interactions between people and birds become particularly important. Capture and use of wildlife are ancient practices and play an important role in acquiring the necessary resources for the subsistence of these populations, either directly or as food source, or indirectly, by obtaining income from the sale of captured animals (Alves et al. 2009). To ensure effectiveness in the acquisition of such resources, human groups developed a set of specific techniques, based on the ecological knowledge of wildlife, developing hunting and gathering strategies that have been traditionally maintained (Alves et al. 2009) and disseminated orally through generations (Bezerra et al. 2013), becoming part of the cultural traditions of the inhabitants of the Caatinga (Alves et al. 2009).

Wild birds are very important in northeastern semiarid livelihood being used as subsistence items (Bezerra et al. 2011; Dantas-Aguiar et al. 2011; Alves et al. 2012; Fernandes-Ferreira et al. 2012; GalvaneLoss et al. 2014; Teixeira et al. 2014; Soares et al. 2018a,b), pets (Alves et al. 2010; Alves et al. 2013; Licarião et al. 2013; Alves Macário et al. 2016), traditional medicines (Bezerra et al. 2013; Soares et al. 2018b), raw material for handicrafts (Alves and Souto 2010; Alves et al. 2013; FernandesFerreira et al. 2012), and associated with symbolic, mystical and religious relations (Alves et al. 2009; 2012; Santos and CostaNeto 2007; Bezerra et al. 2013; Da Silva et al. 2017).

From an economic and social point of view, the exploitation of wild birds in the northeastern semiarid region is protected by the Brazilian Environmental Crimes Law (9605/98), which decriminalizes the hunting and capture of wild animals in case of food demand. This legal permission, somehow, favors the use and the continuing cultural importance of human interaction with wild 
birds (Alves and Souto 2010; 2015). However, are socioeconomic factors still the main determinants of the relationships between people and wild birds? Factors such as income, education and age are the main determinants of human-bird relationships?

Although these human-bird relationships threaten the conservation of wild bird species in Caatinga, there is still a notable uneven distribution of these studies in the region. Most part of the researches are in areas close to universities or research institutes in Paraíba, Rio Grande do Norte and Ceará, with a low number of studies being developed in Bahia, despite of its representativeness in size in northeastern of Brazil. Gaps in investigating the influence of socioeconomic factors on such interactions include modelling the relations between socioeconomic aspects and understanding how local populations perceive the ecological importance of such species in the ecosystem.

Regarding local ecological knowledge on bird biodiversity, some aspects have been investigated: popular names, knowledge of species' habits and behavior (Farias and Alves 2007, Pires-Santos et al. 2015, Andrade 2016) and symbolic relationships culturally constructed (Araujo and Silva 2017, Bezerra et al. 2013). Understanding these relationships is of utmost importance to guide sustainable management strategies based on the level of knowledge and real needs of the local human populations (Alves et al. 2009), and to support educational actions, in order to provide relations of coexistence between people and avifauna (Da Silva et al. 2017).

Therefore, the present study aimed to answer the following question: how does vary the knowledge of the diversity of bird species and the acknowledgement of their ecological importance in the ecosystem in relation to socioeconomic aspects? There is a preconception that socioeconomic factors such as lower family income, longtime settled in the region, elder and male, are causally related to local ecological knowledge about birds' biodiversity, due to a utilitarian dependence and a consequent long lifetime experience. However, it is assumed that knowledge about birds' ecological importance is positively related with the level of formal knowledge. Thus, hypothesis formulated suggest that poverty causes more dependence of natural resources, facilitating knowledge of biodiversity (more dependent, implies more knowledge); time of experience with species and exposure to species influences knowledge of biological diversity; gender influences knowledge of birds biodiversity; and, formal education eases knowledge of biological diversity importance.

\section{MATERIAL AND METHODS}

\section{Study area}

This study was carried out in four communities in the municipality of Casa Nova $\left(09^{\circ} 09^{\prime} 43^{\prime \prime S}, 40^{\circ} 58^{\prime} 15^{\prime \prime} \mathrm{W}\right)$, north of Bahia, in the region of Lower São Francisco River Basin, with an area of 9,647.07 $\mathrm{km}^{2}$ and a population of 64,940 inhabitants (IBGE 2011) (Figure 1): 1 - Recreio (09 21'13"S; 4104'78"W), 2 - Chapada do Avelar (09019'49"S; 4087'77"W), 3 - Lagoa

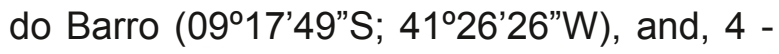
Serra Branca $\left(09^{\circ} 22^{\prime} 03^{\prime \prime} S\right.$; 4086'99'W). These communities were selected because they are easily accessible from the county seat, and they constitute a good model for the analysis of the relations with the birds, according to frequent observations made preliminary to this research, when the region 


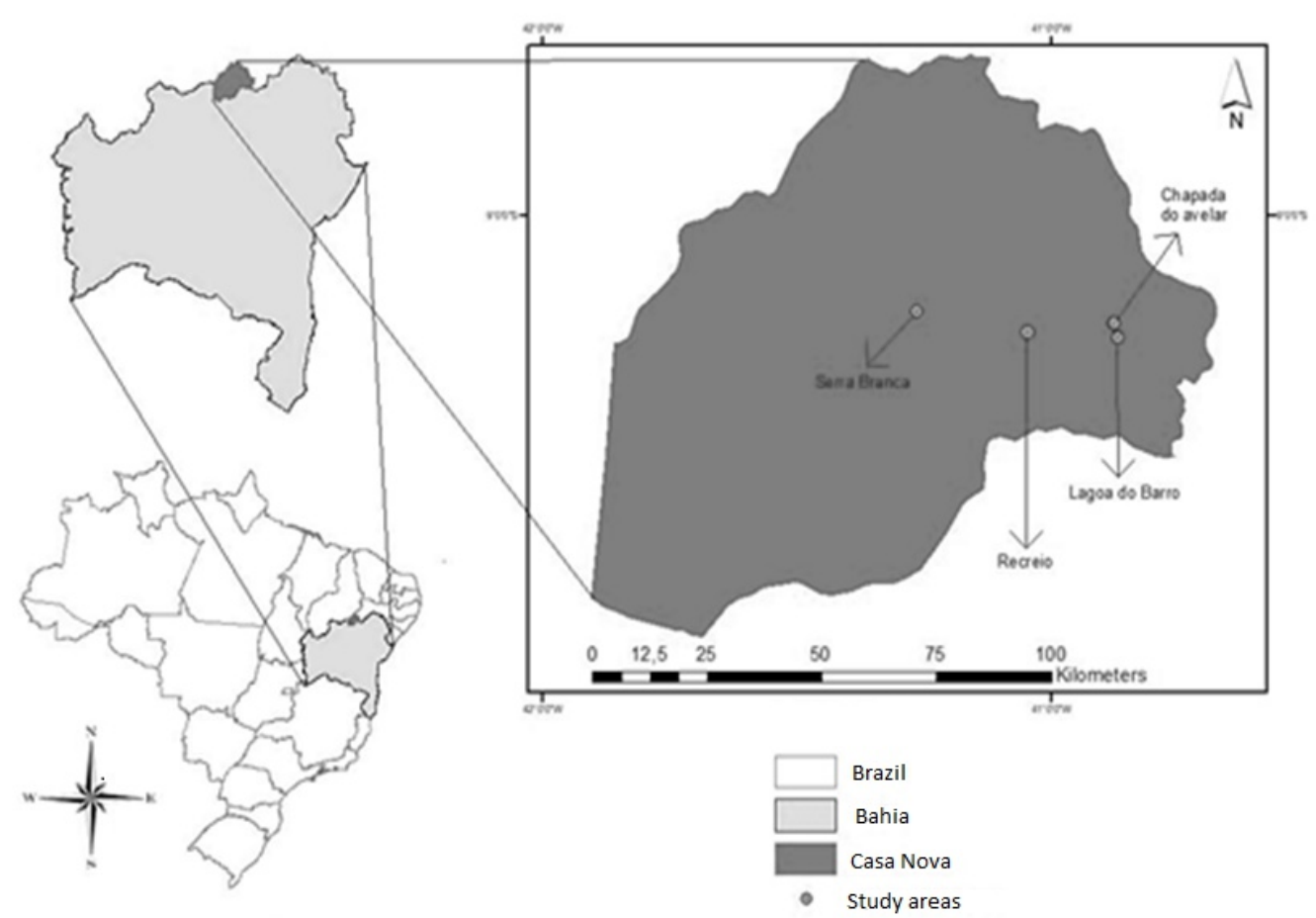

Figure 1. Location map of the study area: Recreio, Chapada do Avelar, Lagoa do Barro and Serra Branca, in the municipality of Casa Nova, Bahia.

was visited to select the collection points.

The municipality' economy includes agricultural and livestock activities, especially goat and sheep ranching. Casa Nova has the largest herd of goats in Bahia $(468,258$ animals representing $4.8 \%$ of Brazilian goat herd) (IBGE 2017a). According to the criteria adopted by the Atlas of Human Development, the HDI of the municipality is considered low (0.570) (PNUD et al. 2013), the average monthly income of the population is 1.5 minimum wages, and in $49.4 \%$ of households the monthly income is up to half a minimum wage per person. Also, the proportion of people working registered in Employment Booklet related to the total population is 9.6\% (IBGE 2017b). The socioeconomic data collected are shown in Table 1-2.

\section{Data collection}

Between December 20, 2018 and March 31,2019 , all the residences of the four communities selected for the study were visited and the residents who volunteered to participate in the survey were interviewed, after signature of authorization for the collection, use and publication of data, required by Brazilian legislation (Resolution n. 466, of $12 / 12 / 2012$, of the National Health Council of Brazil). It was assured by the researchers the confidentiality about the identity of the participants.

A total of 105 participants included 58 $(32.2 \%$ of the total respondents) from Recreio community, 22 (73.3\%) from Chapada do Avelar, 19 (63.3\%) from Lagoa do Barro and 6 (40\%) from Sítio Lagoinha (Serra Branca). Data was obtained through a semi-structured questionnaire, conducted in an informal way so that the participant was more comfortable answering the questions 
Table 1. Socioeconomic profile (gender, age, education, monthly income, residence time in the region) of the respondents in Recreio, Chapada do Avelar, Lagoa do Barro, Serra Branca, municipality of Casa Nova, Bahia, sampled in the period between December 2018 and March 2019. Data outside parentheses correspond to the number of respondents and in parentheses the equivalent percentage.

\begin{tabular}{ll}
\hline Socioeconomic parameters & Number and percentage of respondents \\
\hline Gender & \\
Male & $45(42.86 \%)$ \\
Female & $60(57.14 \%)$ \\
Age & \\
$<20$ & $6(5.7 \%)$ \\
$21-40$ & $62(59 \%)$ \\
$41-60$ & $25(23.8 \%)$ \\
$61-80$ & $11(11.5 \%)$ \\
Education & \\
No school attendance & $15(14.3)$ \\
Incomplete Elementary School & $48(45.7 \%)$ \\
Elementary School & $19(18.1 \%)$ \\
High school & $23(21.9 \%)$ \\
Monthly income & \\
No fixed income & $37(35.2 \%)$ \\
Up to a minimum wage & $61(58.1 \%)$ \\
Between one and two minimum wages & $5(4.8 \%)$ \\
Above three minimum wages & $2(1.9 \%)$ \\
Residence time in the community & \\
$<20$ years & $52(49.5 \%)$ \\
$21-40$ & $41(39.1 \%)$ \\
$41-60$ & $8(7 \%)$ \\
$61-80$ & $4(3.8 \%)$ \\
\hline
\end{tabular}

(according to a method suggested by the participants through popular names were Huntington (2000)).

identified by confirming morphological

The questionnaire protocol was divided into two parts. The first part has questions related to the socioeconomic profile characteristics and/or behavioral and/or vocalization. The classification and nomenclature of the species followed the (predictive variables): gender, age, guidelines of the Brazilian Ornithological educational level, monthly family income, Records Committee (Piacentini et al. 2015). residence time in the community; and the In the analysis of knowledge about the second part, questions related to the ecological importance of species in the knowledge of the person of wild birds environment, participants were expected to (dependent variables): free listing of known cite bird supporting ecosystem services as species (Albuquerque and Lucena 2004) pollinators, seed dispersers, scavengers, and knowledge about the ecological and important as biological pest control importance of species in the environment. (Whelan et al. 2008). The answers related to The socioeconomic variables were the above quoted ecosystem services were categorized and organized by groups, as cumulatively quantified according to the shown in Table 2-3. The birds mentioned by number of ecosystem services informed by 
Table 2. Categorized predictors variables related to socioeconomic data of the respondents in Recreio, Chapada do Avelar, Lagoa do Barro and Serra Branca, municipality of Casa Nova, Bahia, sampled between December 2018 and March 2019. ES: Elementary School, HS: High School, HE: Higher Education.

\begin{tabular}{|c|c|c|c|c|c|c|c|}
\hline Education & Value & $\begin{array}{l}\text { Age } \\
\text { (years) }\end{array}$ & Value & $\begin{array}{l}\text { Income } \\
\text { (minimum wage*) }\end{array}$ & Value & $\begin{array}{l}\text { Residence } \\
\text { time (years) }\end{array}$ & Value \\
\hline No attendance & 0 & $\begin{array}{l}\text { Up to } \\
20\end{array}$ & 1 & $\begin{array}{l}\text { Less than a } \\
\text { minimum wage }\end{array}$ & 1 & Up to 20 & 1 \\
\hline Incomplete ES & 1 & 20 to 40 & 2 & $\begin{array}{l}\text { one to less than a } \\
\text { two minimum } \\
\text { wages }\end{array}$ & 2 & 20 to 40 & 2 \\
\hline Completed ES & 2 & 40 to 60 & 3 & $\begin{array}{l}\text { Two to less than a } \\
\text { three minimum } \\
\text { wages }\end{array}$ & 3 & 40 to 60 & 3 \\
\hline Completed HS & 3 & 60 to 80 & 4 & $\begin{array}{l}\text { three to less than a } \\
\text { four minimum } \\
\text { wages }\end{array}$ & 4 & 60 to 80 & 4 \\
\hline Completed HE & 0 & & 5 & & & & \\
\hline
\end{tabular}

the respondents (0 to 4). For example, if the respondent mentioned: "visits the flowers" and "does not let the insects increase", two functions were assigned correctly, assigning number 2.

The present study follows the instructions suggested by the Declaration of Helsinki and Tokyo for Human Subjects. The ethical approval for the study was issued by the National Commission of Ethics in Research (CONEP) under the number CAAE: 87028717.7.0000.5207, through clearance number 3.051.373.

\section{Data analysis}

The theoretical variable in this research is 'knowledge about the wild birds'. In order to measure it, we defined as operational variables 'richness of known species' (or biological diversity) and 'acknowledgement of the ecological importance of birds in the environment'.

In order to verify if the data followed a normal distribution, we applied the ShapiroWilk test, indicated for small samples (smaller than 500) (Leotti et al. 2012). The level of significance $(p<0.05)$ did not allow us to reject the null hypothesis once the data does not have a normal distribution. Thus, all applied tests are considered non-parametric. The Variance Inflation Factor (VIF) was used to measure the degree of multicollinearity between the predictive variables, which presented an index of less than 4, avoiding the possibility of inflated multicollinearity (O'brien 2007). The general rule is that the VIF should not exceed 10 (Belsley et al. 1980).

The Mann-Whitney test was performed to verify if there were significant differences between men and women in the average citation of species and in the acknowledgement of the ecological importance of the species.

Spearman's correlation analysis was performed to verify the association between predictive variables (socioeconomic data) and dependent variables (richness of known species and acknowledgement of their ecological importance). Then, due to the non-linear distribution of the variables, 
Poisson generalized linear models (GLM) were used to describe the effect of the predictors on the response variable. Poisson GLM is used for data counted as proportions or counting ratios, that is, non-negative integer values (Alvarenga 2015). However, there is a tendency to overdispersion in the Poisson GLM models (Turkman and Silva 2000), which occurs when the variance is greater than the mean (Schmidt 2003). Thus, the dispersion parameter of the model was analyzed through the residual deviance, which resulted in a value greater than 2 . The dispersion parameter allowed for the Poisson family are values $\leq 1$ (Provete et al. 2011). Due to the overdispersion, we made use of the Binomial Regression Model as recommended by several authors (Alvarenga 2015; Tadano et al. 2009).

The stepwise backward selection was used, i.e., from the generated global model, the least significant predictive variables were eliminated one by one (Alvarenga 2015). The AIC (Akaike Information Criteria) values were compared to evaluate the model that best explains the variation of the data, including the generated null model. The lower the AIC value, the less information will be lost and, therefore, the better the model will be adjusted (Alvarenga 2015). The Delta AIC $(\Delta \mathrm{i})$ was calculated to rank the models in increasing order of relevance (low to high), which used as a measure of each model in relation to the best model, considering that: $\Delta \mathrm{i}<2$ suggests substantial evidence for the model; $\Delta \mathrm{i}$ between 3 and 7 indicates that the model has considerably less support; and, $\Delta \mathrm{i}>10$ indicates that the model is highly unlikely (Mazerolle 2004).

It was established a significance level less than or equal to 0.05 ( $p \leq 0.05)$ for all tests. Statistical analysis was performed using software "R" (R CORE TEAM 2018), with packages support: 'car' (Fox and Weisberg 2011), 'MASS' (Venables and Riplay 2002), 'lattice' (Sarkar 2008), 'MuMIn' (Barton 2019), 'bbmle' (Bolker 2017), and 'ggplot2' (Wickham 2016).

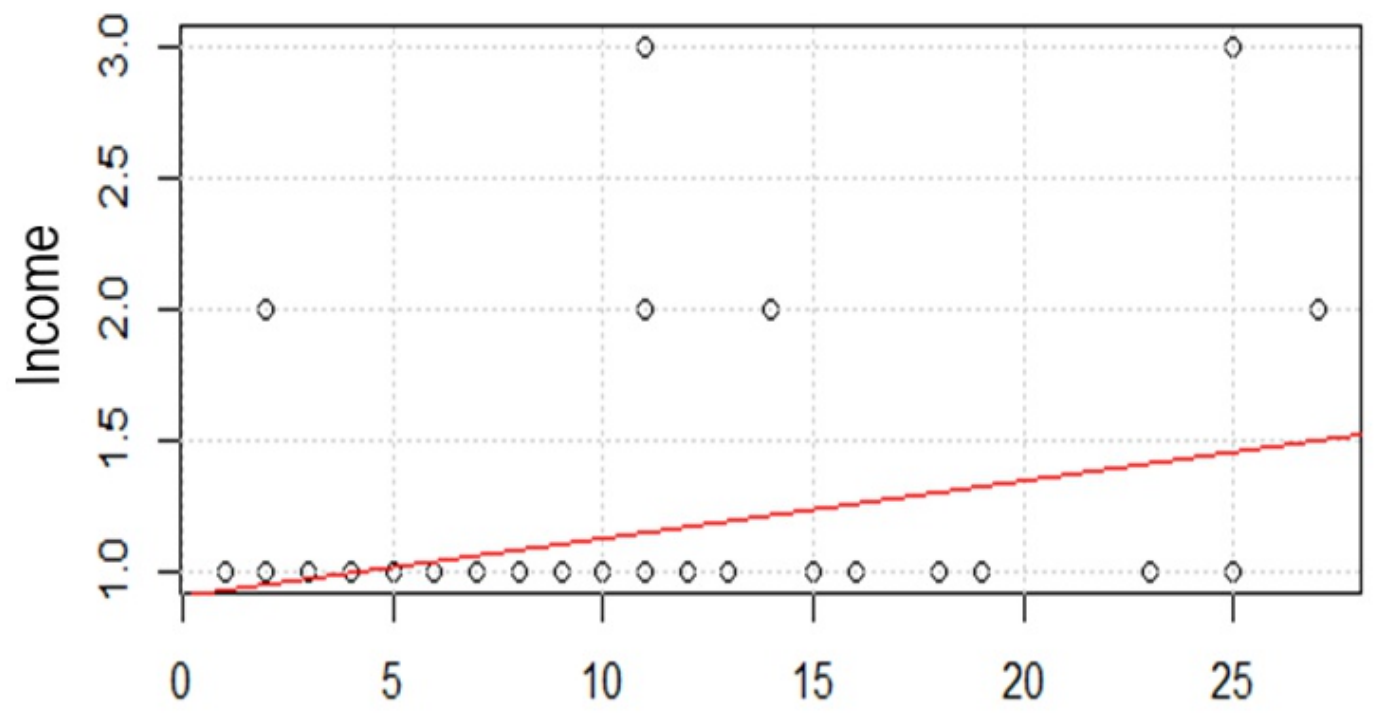

\section{Number of bird species cited}

Figure 2. Correlation between the number of bird species cited and income of the respondents of Casa Nova, Bahia. 


\section{RESULTS AND DISCUSSION}

\section{Does dependence on natural resources promote knowledge on biological diversity?}

The respondents made 840 bird citations, totaling 60 species, belonging to 19 orders and 30 families (Table 3-4).

There was a positive correlation between the number of bird species known to the respondents and their income $(p=0.01$, rho 0.24) (Figure 2). Thus, the higher the income, the greater the number of species cited. Regarding knowledge about the ecological importance of bird diversity in the environment, there was no correlation with the respondents' income.

This positive correlation between income and the number of bird species cited does not corroborate the initial hypothesis that a lower income causes the dependence of natural resources that favors the knowledge of biological diversity. Hunting in this region may be directed to the acquisition of extra income, in order to raise the consumption pattern of the individuals involved, likewise Swamy and Pinedo-Vasquez (2014) argument that the hunting of wild animals in tropical forests contributes more to generate extra income, to increase the purchasing power of consumer durable goods and hardly for the acquisition of subsistence items. Results in this study is consistent with Duffy et al. (2016) questionings on the links between poverty and illegal wildlife hunting, still prevailing in powerful policy arenas.

\section{Does the exposition and experience} with the species influences the knowledge on the biological diversity?

There was positive correlation between the number of bird species named by the respondents and respondents age $(p=0.01$, rho $=0.24)$ and their residence time in the region ( $p=0.01$, rho $=0.27)$ (Figure 3$)$. However, there was no significant correlation between age and residence time in the region with the acknowledgement of birds' ecological importance. It was observed a relation between age and gender concerning female respondents, with the higher number of species cited $(n=27)$ by an elder female respondent (age group $=60-80$ years old).
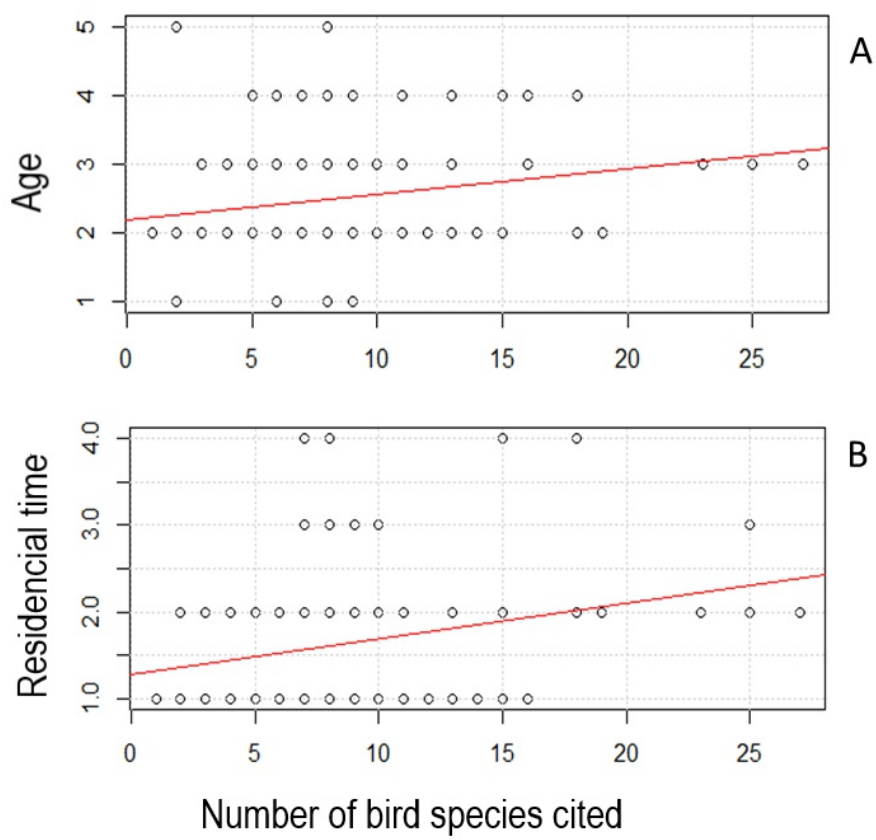

Figure 3. Correlation between the number of bird species cited and age $(A)$ and residence time $(B)$ of respondents in Casa Nova, Bahia. 
Table 3. Species of birds cited by the respondents, with their respective citation frequencies (\%) (number of citations / number of respondents) $\times 100$ ), in the municipality of Casa Nova, Bahia, from December 2018 to March 2019, with taxonomic characterization: order, family, scientific name, popular names in Portuguese and English, according Piacentini et al. (2015).

\begin{tabular}{|c|c|c|c|c|c|}
\hline & Order & Family & Scientific Name & Popular name (Portuguese) & Popular name (English) \\
\hline 01 & RHEIFORMES & Rheidae & Rhea americana & Ema & Greater Rhea \\
\hline 02 & TINAMIFORMES & Tinamidae & Crypturellus parvirostris & Inhambu & Small-billed Tinamou \\
\hline 03 & & & Rhynchotus rufescens & Perdiz & Red-winged Tinamou \\
\hline 04 & & & Nothura boraquira & Codorna & White-bellied Nothura \\
\hline 05 & ANSERIFORMES & Anatidae & Dendrocygna autumnalis & Marreca cabloca & Whistling-Duck \\
\hline 06 & & & Netta erythrophthalma & Paturi preto & Southern Pochard \\
\hline 07 & GALLIFORMES & Cracidae & Penelopepe jacucaca & Jacucaca & White-browed Guan \\
\hline 08 & PELECANIFORMES & Ardeidae & Bubulcus ibis & Garça vaqueira & Cattle Egret \\
\hline 09 & CATHARTIFORMES & Cathartidae & Coragyps atratus & Urubu & Black Vulture \\
\hline 10 & ACCIPITRIFORMES & Accipitridae & Rupornis magnirostris & Gavião carijó & Roadside Hawk \\
\hline 11 & GRUIFORMES & Rallidae & Gallinula galeata & galinha-d'agua & Common Gallinule \\
\hline 12 & CHARADRIIFORMES & Charadriidae & Vanellus chilensis & Quero quero & Southern Lapwing \\
\hline 13 & COLUMBIFORMES & Columbidae & Columbina talpacoti & Rolinha Roxa & Ruddy Ground-Dove \\
\hline 14 & & & Columbina squammata & Rolinha Cascavel & Scaled Dove \\
\hline 15 & & & Columbina picui & Pombinha branca & Picui Ground-Dove \\
\hline 16 & & & Patagioenas picazuro & Asa branca & Picazuro Pigeon \\
\hline 17 & & & Zenaida auriculata & Avoante & Eared Dove \\
\hline 18 & & & Leptotila verreauxi & Juriti pupu & White-tipped Dove \\
\hline 19 & CUCULIFORMES & Cuculidae & Piaya cayana & Alma de gato & Squirrel Cuckoo \\
\hline 20 & & & Crotophaga ani & Anu preto & Smooth-billed Ani \\
\hline 21 & & & Guira guira & Anu branco & Guira Cuckoo \\
\hline 22 & STRIGIFORMES & Strigidae & Glaucidium brasilianum & Caburé & Ferruginous Pygmy-Owl \\
\hline 23 & & & Athene cunicularia & Coruja buraqueira & Burrowing Owl \\
\hline 24 & APODIFORMES & Trochilidae & Eupetomena macroura & beija-flor-tesoura & Swallow-tailed Hummingbird \\
\hline 25 & GALBULIFORMES & Bucconidae & Nystalus maculatus & Cava chão & Spot-backed Puffbird \\
\hline 26 & PICIFORMES & Picidae & Colaptes melanochloros & pica-pau-verde-barrado & Green-barred Woodpecker \\
\hline 27 & CARIAMIFORMES & Cariamidae & Cariama cristata & Seriema & Red-legged Seriema \\
\hline 28 & FALCONIFORMES & Falconidae & Caracara plancus & Carcará & Southern Caracara \\
\hline 29 & & & Herpetotheres cachinnans & Acauã & Laughing Falcon \\
\hline 30 & PSITTACIFORMES & Psittacidae & Primolius marcana & Maracanã & Blue-winged Macaw \\
\hline 31 & & & Eupsittula cactorum & Periquitinha & Cactus Parakeet \\
\hline 32 & & & Forpus xanthopterygius & Periquitinha s.josé & Blue-winged Parrotlet \\
\hline 33 & & & Amazona aestiva & Papagaio & Turquoise-fronted Parrot \\
\hline 34 & PASSERIFORMES & Furnariidae & Pseudoseisura cristata & Casaca de couro & Caatinga Cacholote \\
\hline 35 & & Tyrannidae & Stigmatura napensis & Papa moscas & Lesser Wagtail-Tyrant \\
\hline 36 & & & Myiarchus tyrannulus & maria-cavaleira-de-rabo-enferrujado & Brown-crested Flycatcher \\
\hline 37 & & & Pitangus sulphuratus & Bem-te-vi & Great Kiskadee \\
\hline 38 & & & Fluvicola nengeta & Lavadeira-mascarada & Masked Water-Tyrant \\
\hline 39 & & Corvidae & Cyanocorax cyanopogon & Cancão & White-naped Jay \\
\hline 40 & & Hirundinidae & Progne tapera & andorinha-do-campo; & Brown-chested Martin \\
\hline 41 & & Troglodytidae & Troglodytes musculus & Corruíra & Southern House Wren \\
\hline 42 & & Turdidae & Turdus rufiventris & Sabiá laranjeira & Rufous-bellied Thrush \\
\hline 43 & & Mimidae & Mimus saturninus & Sabiá do campo & Chalk-browed Mockingbird \\
\hline 44 & & Icteridae & Icterus pyrrhopterus & Pêga & Variable Oriole \\
\hline 45 & & & Icterus jamacaii & Sofrê, corrupião & Campo Troupial \\
\hline 46 & & & Gnorimopsar chopi & Pássaro preto & Chopi Blackbird \\
\hline 47 & & & Molothrus bonariensis & Chupinho & Shiny Cowbird \\
\hline 48 & & Thraupidae & Paroaria dominicana & Cardeal-do-nordeste & Red-cowled Cardinal \\
\hline 49 & & & Sicalis flaveola & Canário da Terra & Saffron Finch \\
\hline 50 & & & Coryphospingus pileatus & Maria fita & Pileated Finch \\
\hline 51 & & & Coereba flaveola & Cambacica & Bananaquit \\
\hline 52 & & & Sporophila lineola & Bigodinho & Lined Seedeater \\
\hline 53 & & & Sporophila nigricollis & Baiano & Yellow-bellied Seedeater \\
\hline 54 & & & Sporophila caerulescens & Coleirinho & Double-collared Seedeater \\
\hline 55 & & & Sporophila albogularis & Golinho & White-throated Seedeater \\
\hline 56 & & & Sporophila bouvreuil & Caboclinho & Copper Seedeater \\
\hline 57 & & & Saltator coerulescens & sabia-gongá & Grayish Saltator \\
\hline 58 & & Cardinalidae & Cyanoloxia brissonii & Azulão & Ultramarine Grosbeak \\
\hline 59 & & Fringillidae & Euphonia chlorotica & Fim fim & Purple-throated Euphonia \\
\hline 60 & & Passeridae & Passer domesticus & Pardal & House Sparrow \\
\hline
\end{tabular}


Our results show that knowledge related to local wild birds is influenced by exposition to, and experience with, the species. Positive correlation between age and number of known species might be related to individuals' life experience and, probably, to improvements in livelihood, considering that youngest generations have an easier access to more and more diverse resources to survive than those adults had with their age. This supports initial hypothesis that experience with species impacts knowledge on biological diversity. Quilan and Quilan (2007) highlight a trend in knowledge about natural resources according to elderly, once a long lifetime provides more experience opportunities, beyond the fact that this group is less vulnerable to external factors that might interfere in the spread of knowledge about one subject. Musila et al. (2018) observed that elder people belief less in wrong myths about bats in Kenya: authors suggest that longer life that accumulate experiences, along with more time to interact with nature, could transform myths learned as youths in more realistic perceptions of nature.

Other aspect to be considered to reduce knowledge of new generations is the local decline or extinction of species, which decreases the sighting of many species. Farias and Alves (2007) indicate the biological diversity loss as a constraint for young generations to build social representations of locally non-sighted species, leading to impoverishment on transfer of traditional knowledge on wild birds. Kai et al. (2014) describe the extinction of bird species in Southeast China as a key factor for local knowledge erosion, especially among youngest generations unable to birdwatching and listen to birds' songs in the wild.

Recent changes in rural infrastructures on the sampled communities, such as electricity and consequent improvements on communication (television, mobile phones, radio and others), seem to decrease the youngest populations interest on outdoor activities, thus, they build a weak empirical knowledge on local biodiversity. Pergams and Zaradic (2006), Hofferth (2009) and Ballouard et al. (2011) highlight that direct contact with nature is being replaced by virtual experiences. Henderson et al. (2011) and Green et al. (2012) bring light to the lost of interaction with nature, especially in western countries, which causes decrease in knowledge about environment and ability to identify species, even the common ones. Cassey and Hogg (2015) state that to have the minimum capacity to identify species is a first requirement to understand and appreciate biodiversity, once species are its key element. Soga and Gatson (2016) state that decrease of interactions with environment, especially of young ones, causes loss of experience and devaluing of natural heritage, which becomes a bottleneck for conservation once human connection with nature changes people's feelings of love and motivation for protection.

\section{Are there differences between genders on biodiversity knowledge?}

Data show statistically significant differences between the number of cited species related to respondent gender $(U=1.71 ; p=0.02)$. Men $(n=40)$ named, in average, more species than women $(n=65)$ (Average: $\quad \operatorname{men}=9.3$; $\quad$ women=7.6). Nevertheless, there was no significant difference between this variable and knowledge on ecological importance of birds $(U=1.33 ; p=0.89)$. The effect of gender and age on the knowledge of wild birds corroborate Alves et al. (2010) research, in 
which elder men and women are better able to identify species at group level. It corroborates previous findings of Pam et al. (2018), who stated that hunting birds is a boy's activity, which allows them to know and find more birds than girls, who do not engage with hunting.

Alves et al. (2012) and Da Silva et al. (2017), in studies in Brazilian northeastern semiarid, also identified difference between the number of species among genders, with male respondents naming higher number of wild bird species. The better knowledge detained by men is probably related to the ancient cultural method of tasks division, with outdoor activities under the responsibility of men (Da Silva et al. 2017). Traditionally, poaching is seen as a practice that adds social prestige and bravery to the man (Vargas-Tovar 2000). From early age, mainly boys accompany their fathers in capturing wildlife, activity from which they acquire sound knowledge about bird species, their habits and behavior.

Does formal education enhance knowledge on biological diversity importance?

There was no significant correlation between the educational level of the respondents and the number of species named $(p=0.11, \quad$ rho $=-0.15)$ and the acknowledgment of wild birds' ecological importance. Results show that formal education does not significantly interfere on knowledge about diversity of birds or on the acknowledgment of their ecological importance in ecosystems. However, Figure 4 shows a trend relating higher education with lower number of species named.

Oliveira (2011) observed that people with higher education have less knowledge about wildlife and people with lower education know more about wildlife because it becomes resources from which they depend for their survival. Thus, the absence of a positive correlation between educational level and individual ecological knowledge may reflect a fundamental educational system that does not connect science and traditional knowledge, through practical experiences and awareness of local reality. Furthermore, Musila et al. (2018) found positive correlation between the higher level of schooling and lower beliefs in myths and positive attitudes towards science and ecology of bats in Kenya. This stresses the important role of formal education for biodiversity conservation, although the importance of educational interventions of governmental and non-governmental institutions.

\section{How do socioeconomic factors} jointly interfere in the knowledge about wild bird species?

A global model of negative binomial regression was performed, the parameters of which are presented in Table 4-5. Other nested models were built deriving from global model through stepwise backward selection (Table 5-6). Comparing Delta AIC $(\Delta \mathrm{i})$ values (Table 6-7) it is possible to verify that global model, model 1 and model 2 show values below 2 and, in that case, are considered the better adjusted to the collected data. Model 1 presents the lowest $\Delta \mathrm{i}$ and shows that the socioeconomic variables: income, age and residence time together better explain the pattern observed for the number of wild bird species mentioned. The ratio between the weight of the best model (model 1) and the weight of the second best model (global model), following Mazerolle (2004) method, shows that the first one has a chance of 1.43 of 


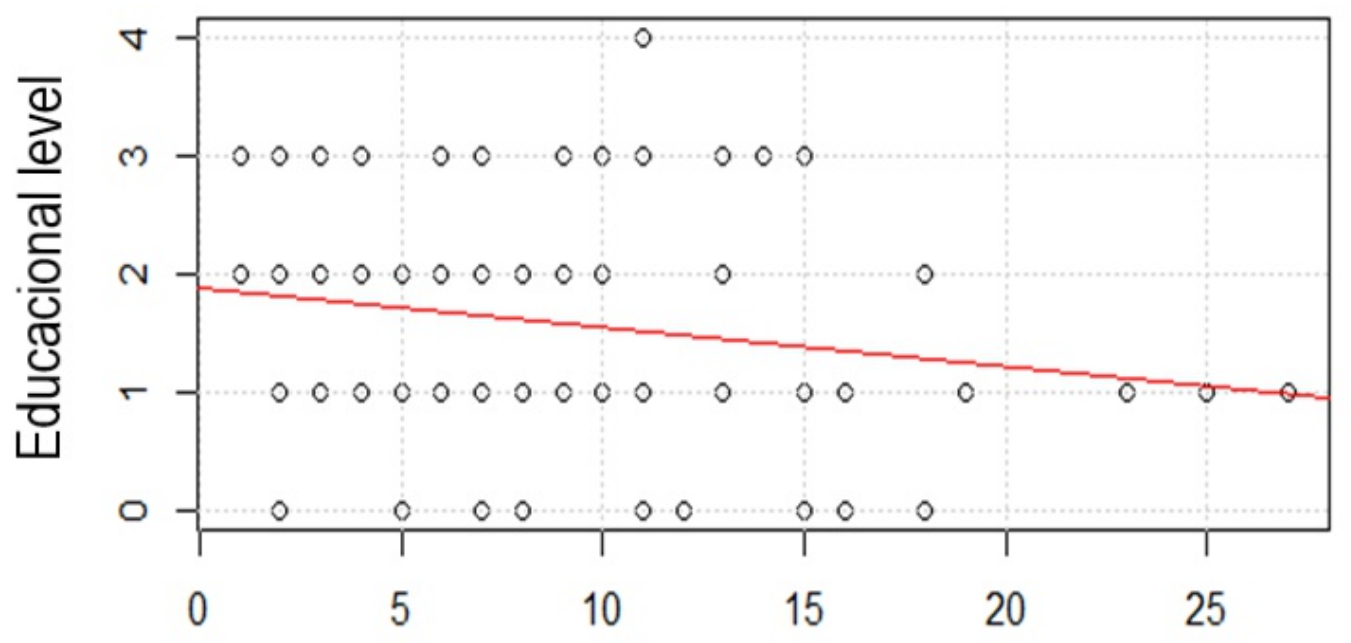

Number of bird species cited

Figure 4. Correlation between number of species named and educational level of respondents in Casa Nova, Bahia.

Table 4. Estimated parameters of the negative binomial global model with explanatory variables: age, educational level, income and residence time, and, dependent variable: number of cited bird species in Casa Nova, Bahia.

\begin{tabular}{lllll}
\hline & Estimate & Std. error & Z value & $\operatorname{Pr}(>|\mathbf{z}|)$ \\
\hline Intercept & 1.27626 & 0.26609 & 4.796 & $1.62 \mathrm{e}-06^{* * *}$ \\
Age & 0.09622 & 0.06713 & 1.433 & 0.15175 \\
Education & -0.07313 & 0.05903 & -1.239 & 0.21535 \\
Income & 0.43302 & 0.14308 & 3.026 & $0.00247^{* *}$ \\
Residence time & 0.13324 & 0.07452 & 1.788 & 0.07378 \\
\hline
\end{tabular}

being better than the global model, and 1.66 related to model 2, which lead us to conclude that although model 1 is considered the best, it is not possible to ignore education as a socioeconomic factor with impact on the knowledge of wild bird diversity in the region.

It is noteworthy that individually the variables income, residence time and age were elected as the best predictive variables for the knowledge on bird species. This result is consistent with other studies in northeastern region (Alves et al 2012; Da Silva et al 2017), that associate socioeconomic factors such as gender, fauna is very restricted. educational level, income, professional occupation and age to knowledge and use of wildlife in northeastern semiarid. Quite few studies analyze and compare models with different associations among socioeconomic factors. Castilla et al. (2020) used a GLM analyses and found a positive perception about bats in Escaba region (Tucumán province, Argentina) related to age and in people who concluded fundamental schooling. However, authors did not compare different models, thus any understanding of how socioeconomic factors impact knowledge and perception towards 
Table 5. Estimated parameters of the negative binomial nested models with explanatory variables: age, educational level, income and residence time, and, dependent variable: number of cited bird species in Casa Nova, Bahia. Nested models: model 1: number of cited species $\sim$ income + age + residence time); model 2: number of cited species $\sim$ income + residence time and model 3: number of cited species $\sim$ income.

\begin{tabular}{lllll}
\hline Estimate & Model 1 & Model 2 & Model 3 & Null model \\
\hline Intercept & 1.10413 & 1.3453 & 1.6187 & 2.11683 \\
Income & 0.40083 & 0.3967 & 0.4457 & \\
Age & 0.11922 & & & \\
Residence time & 0.15470 & 0.1950 & & \\
\hline
\end{tabular}

Table 7. Global model, nested models and null model with values of Akaike information criteria (AIC), delta AIC $(\Delta \mathrm{i})$, degrees of freedom (df) and weight.

\begin{tabular}{lllll}
\hline Model & AIC & $\mathbf{\Delta i}$ & df & Weight \\
\hline $\begin{array}{l}\text { Global: }\left(\mathrm{n}^{\circ} \text { of known species } \sim \text { income + age + residence time }+\right. \\
\text { educational level) }\end{array}$ & 603.77 & 0.7 & 6 & 0.298 \\
Model 1: ( $\mathrm{n}^{\circ}$ of known species $\sim$ income + age + residence time) & 603.3 & 0.0 & 5 & 0.426 \\
Model 2: ( $\mathrm{n}^{\circ}$ of known species $\sim$ income + residence time) & 604.53 & 1.0 & 4 & 0.256 \\
Model 3: $\left(\mathrm{n}^{\circ}\right.$ of known species $\sim$ income) & 609.95 & 6.3 & 3 & 0.018 \\
Null model & 617.28 & 13.5 & 2 & $<0.001$ \\
\hline
\end{tabular}

The lack of correlation between socioeconomic variables and acknowledgment of ecological importance of wild birds is probably related to the low number of respondents who named at least one ecological function of birds in the ecosystem. Only $6 \%(n=6)$ know at least two functions and $18 \%(n=19)$ know the function related to seed dispersal. It is noteworthy that most of the respondents $(76 \%)$ did not mention any environmental services provided by wild birds, still mention to value biodiversity, stating the importance of their protection based on utilitarian, affective and cultural criteria, as some quotes herewith:

"For them to sing early in the morning, it is so beautiful!"

"For them to reproduce and have freedom, no one wants to live caged"

"For our grandchildren to see, it is so good, we can watch them, they have the same right".

"They are the joy of sertão".

These results corroborate Alves-Barbosa and Barbosa (2011) findings, in the semiarid region of Paraíba state, in which 78 (100\%) of respondents defined "animal" according to utilitarian, affective and conceptual criteria, ranking them from especially important to less important. Pam et al. (2018) describe similar situation in a study with 50 Nigerian children, questioning them about birds' importance: $73 \%$ mentioned "food", 9\% aesthetical aspects, $7 \%$, commercial value, $7 \%$, plague (compete for planted crops), $2 \%$, pet, and $5 \%$, no value at all, just because they are not humans. These authors findings oppose to Kellert (1985) who stated that children tend to attribute less a utilitarian value to wildlife than adults. Different contexts may be the cause and further 
studies are required.

It is important to highlight that interactions between wild birds and ecosystem are highly important for biodiversity conservation and the maintenance of the Caatinga ecosystem services (Araujo and Silva 2017), with several mutualistic interactions (Leal et al. 2011) among endemic species or restricteddistribution species (Quesada et al. 2011; Sobrinho et al. 2016). In Caatinga studies prove the existence of several ornithocoric plant species, i.e., when seed dispersal depends totally on wild birds (Griz and Machado 2001), like pollination by hummingbirds on $15 \%$ of native vegetation (Machado and Lopes 2004). Furthermore, roles of wild birds include organic matter cycling and biological pest control, thus, individuals removed from wild for consumption or pet fail to perform key functions to the environment.

The lack of knowledge about the ecological importance of the birds might lead to overvalue of human interests' criteria and non-ecological criteria, with negative consequences for species due to specimens removal from wild, fostering their decline and extinction (Alves et al. 2012; Dirzo et al. 2014; Nascimento et al. 2015; Rocha et al. 2017), compromising important ecological services provided to ecosystem. Changes or deprivation of such services may cause a cascade effect at several ecological levels, including resilience (Leal et al. 2018). Efforts on formal education that aims to change perspectives about ecosystem services provided by avifauna may be an essential investment to promote behavior and attitude changes towards birds and environment.

\section{CONCLUSIONS}

Socioeconomic factors strongly influence the knowledge people have about bird species in their region. Exposure to wild birds and experience with it, gender, education and income together influence the knowledge about the diversity of this group, even considering that the best predictive model was the one including the variables age, time of residence and income. Elder men, residing in the region for long time know more species of wild birds. It was observed that even those socioeconomic factors with single low impact, when combined had an influence on that variable. Thus, further studies are recommended using models to explain the synergic influence of such factors.

Income showed a positive relation with the knowledge of the local wild bird species. This causality is not clear because it was expected that people with lower income would know more bird species, for the utilitarian importance of the group to their livelihood. However, results did not corroborate this hypothesis and the relationship might be explained by the acquisition of extra income with the use and consequent knowledge of the wild birds. Therefore, further studies detailing these relationships are necessary.

Our results also indicate a reduction in the level of knowledge about bird species among younger populations. From the conservationist point of view this is important because it indicates a reduction of hunting activities (positive impact) and a trend of knowledge erosion and consequent loss of environmental awareness due to lack of connection with nature, devaluing biological heritage (negative impact). For further insights on this subject, we recommend work with focal groups, of children and youths. 
The weak correlation between formal education and knowledge of local biodiversity as well as the acknowledgement of the ecological importance of species, seems to indicate a probable lack of articulation between scientific and traditional knowledge in schools, which should be considered in environmental education programs.

We highlight the relevance of permanent educational measures including different age groups, in order to reconnect a wide range of people with nature, fostering a behavior change in favor of wild birds based on the ecological importance of this group in the ecosystem.

\section{ACKOWLEDGEMENTS}

We are very grateful to the residents of Casa Nova communities who were available and willing to participate in the research. Also to CONEP for the permission and clarification provided so that the research attended the Brazilian ethical standards. We are also thankful to Dr. Rebeca M. Barreto and Dr. Washington F. Soares for their suggestions and valuable contributions to our work.

\section{Data availability}

The quantitative data (except the data that may lead to the respondent) used to support the findings of this study are available from the corresponding author upon reasonable request.

\section{Conflicts of interest}

There was not and there is not conflict of interest among the authors.

\section{Contribution statement}

Conceived of the presented idea: SSNS, FCM.

Carried out the experiment: SSNS.

Carried out the data analysis: SSNS, FCM.

Wrote the first draft of the manuscript: SSNS, FCM.

Review and final write of the manuscript: SSNS, FCM, CSGM.

Supervision: SSNS, FCM, CSGM.

\section{REFERENCES}

Albuquerque UP, Lucena RFP (2004). Métodos e técnicas para a coleta de dados. In: Albuquerque UP, Lucena RFP. (Org.). Métodos e técnicas na pesquisa etnobotânica. NUPEEA/ Livro Rápido, Recife, pp. 37-62.

Alvarenga AMT (2015). Modelos lineares generalizados: aplicação a dados de acidentes rodoviários. Dissertação de mestrado, Universidade de Lisboa, Lisboa, PT.

Alves Barbosa JA, Barbosa, RKVC (2011). Percepção de moradores do semiárido paraibano sobre a diversidade e relevância da fauna em duas comunidades rurais. Revista de Biologia e Ciências da Terra, 11 (1): 123-133.

Alves Macário M, Faria SL, Alves RRN (2016). Wild vertebrates kept as pets in the semiarid region of Brazil. Tropical Conservation Science 9(1): 354-368.

Alves RRN, Alves Barbosa JA, Santos SL, Souto W, Barboza RR (2011). Animal based remedies as complementary Medicines in the semi-arid region of Northeastern Brazil. Evidence-based Complementary and Alternative Medicine 3:1-13.

Alves RRN, Gonçalves MBR, Vieira W (2012). Hunting, use and conservation of vertebrates in the Brazilian semiarid. Tropical Conservation Science 5: 394-416.

Alves RRN, Leite RCL, Souto WMS, Bezerra DM, Ribeiro AL (2013). Ethno-ornithology and conservation of wild birds in the semi-arid Caatinga of northeastern Brazil. Journal of Ethnobiology and Ethnomedicine 9: 14. 
Alves RRN, Mendonça LE, Confessor MV, Vieira WL, Lopez LC (2009). Hunting strategies used in the semi-arid region of northeastern Brazil. Journal of Ethnobiology and Ethnomedicine 5: 12.

Alves RRN, Nogueira EEG, Araújo HFP, Brooks SE. (2010). Bird-keeping in the Caatinga, NE Brasil. Human Ecology 38: 147 - 156.

Alves RRN, Souto WMS (2010). Etnozoologia: conceitos, considerações históricas e importância. In: Alves RRN, Souto WMS, Mourão JS (eds) A Etnozoologia no Brasil: Importância, Status atual e Perspectivas. 1 ed. NUPEEA, Recife, PE, Brazil, pp. 19-40.

Alves RRN, Souto WMS (2015). Ethnozoology: a brief introduction. Ethnobiology and Conservation 4:1-13.

Andrade HMLS (2016). Influências das agriculturas sobre a avifauna no semiárido de Pernambuco: percepção voltada à Etnoornitologia, Agroecologia e conservação. Dissertação de Mestrado, Universidade Federal Rural de Pernambuco, Recife, Br.

Araujo HFP, Silva JMC (2017). The Avifauna of the Caatinga: Biogeography, Ecology, and Conservation. In: Silva JMC, Leal IR, Tabarelli $M$ (eds.) Caatinga. The largest tropical dry forest region in South America. Springer International Publishing, pp. 181-210.

Ballouard JM, Brischoux F, Bonnet X (2011). Children prioritize virtual exotic biodiversity over local biodiversity. Plos One 6: e 23152.

Barton K (2019). MuMIn: Multi-Model Inference. $\mathbf{R}$ package version 1.43.6. [https:// CRAN.R-project.org/package=MuMIn].

Belsley DA, Kuh E, Welsch R E (1980). Regression Diagnostics: Identifying Influential Data and Sources of Collinearity. New York: John Wiley.

Bezerra, DMM, Araujo, HFP, Alves RRN (2011). Avifauna silvestre como recurso alimentar em áreas de semiárido no estado do Rio Grande do Norte, Brasil. Sitientibus Série Ciências Biológicas 11(2): 177-183.

Bezerra DMM, Araujo HFP, Alves RRN (2012). Captura de aves silvestres no semiárido brasileiro: técnicas cinegéticas e implicações para conservação. Tropical Conservation Science 5(1): 50-66.
Bezerra DMM, Araujo HFP, Alves ÂGC, Alves, RRN (2013). Birds and people in semiarid northeastern Brazil: symbolic and medicinal relationships. Journal of Ethnobiology and Ethnomedicine 9:3 doi: 10.1186/1746-4269-9-3.

Bolker B (2017). And R Development Core Team bbmle: Tools for General Maximum Likelihood Estimation. $\mathrm{R}$ package version 1.0.20. [https://CRAN.R-project.org/ package $=$ bbmle].

Cassey P, Hogg C (2015). Escaping captivity: the biological invasion risk from vertebrate species in zoos. Biol Conserv. 181(1):18-26.

Castilla MC, Campos C, Colantonio S, Díaz M (2020). Perceptions and attitudes of the local people towards bats in the surroundings of the big colony of Tadarida brasiliensis in the Escaba dam (Tucumán, Argentina). Ethnobiology and Conservation 9: 1-14. Retrieved from https://ethnobioconservation.com/ index.php/ebc/article/view/251

Dantas-Aguiar PM, Barreto RM, Santos-Fita D, Santos EB (2011). Hunting activities and wild fauna use: a profile of queixo d'antas community, Campo Formoso, Bahia, Brazil. Bioremediation, Biodiversity and Bioavailability 5(1): 34-43.

Da Silva C, Silva TL, White BLA (2017). Aversão à espécies de aves por moradores da zona urbana e rural do município de Itabaiana, Sergipe, Brasil. Etnobiologia 15(2): 5-15.

Dirzo R, Young HS, Galetti M, Ceballos G, Isaac NJB, Collen B (2014). Defaunation in the Anthropocene. Science 345(6195), 401-406.

Drew JA (2005). Use of Traditional Ecological Knowledge in Marine Conservation. Conservation Biology 19: 1286-1293.

Duffy R, Freya AV, St J. B. Buscher and D. Brockington (2016). Toward a new understanding of the links between poverty and illegal wildlife hunting. Conservation Biology 30(1): 14-22.

Farias GB, Alves AGC (2007). Nomenclatura e classificação etnoornitológica em fragmentos de Mata Atlântica em Igarassu, Região Metropolitana do Recife, Pernambuco. Revista Brasileira de Ornitologia 15: 358-366. 
Fernandes-Ferreira H, Mendonça SV, Albano C, Ferreira FS, Alves RRN (2010). Comércio e criação de aves silvestres (Psittaciformes, Piciformes e Passeriformes) no Estado do Ceará. In: Alves RRN, Souto WMS, Mourão JS (eds) A etnozoologia no Brasil: Importância, Status atual e Perspectivas. 1 ed. NUPEEA, Recife, PE, Brazil, pp. 381-402.

Fernandes-Ferreira H, Mendonça SV, Albano C, Ferreira FS, Alves, RRN (2012). Hunting use and conservation of birds in Northeast Brazil. Biodiversity and Conservation Hunting use and conservation of birds in Northeast Brazil. Biodiversity and Conservation 21(1): 221-244.

Fox J, Weisberg S (2011). An \{R\} Companion to Applied Regression, Second Edition. Thousand Oaks CA: Sage. [http:// socserv.socsci.mcmaster.ca/jfox/Books/

Companion].

Galvane-Loss AT, Costa-Neto EM, Flores FM (2014). Aves silvestres utilizadas como recurso trófico pelos moradores do povoado de Pedra Branca, Santa Teresinha, Bahia, Brasil. Gaia Scientia Volume especial: populações tradicionais. [http://periodicos.ufpb.br/ ojs2/index.php/gaia/index].

Green SJ, Akins JL, Maljković A, Cote IM (2012). Invasive lionfish drive Atlantic coral reef fish declines. PLoS One.; 7(3):e32596. doi: 10.1371/ journal.pone.0032596 PMID: 22412895.

Griz LMS, Machado IC (2001). "Fruiting phenology and seed dispersal syndromes in Caatinga, a tropical dry forest in the northeast of Brazil'". Journal of Tropical Ecology 17:303-321.

Henderson W, Bomford M (2011). Cassey P. Managing the risk of exotic vertebrate incursions in Australia. Wildl Res.; 38(6):501-508.

Hofferth SL (2009). Changes in American children's time - 1997 to 2003. Electronic Int J Time Use Res 6: 26-47.

Huntington HP (2000). Usando conhecimento ecológico tradicional na ciência: Métodos e Aplicações. Ecological Applications 10 (5): 1270 $-1274$.

IBGE (2011). Sinopse do censo demográfico 2010. IBGE, Rio de Janeiro, RJ, Br [https:// biblioteca.ibge.gov.br/visualizacao/livros/ liv49230.pdf].

IBGE (2017a). Pesquisa da Pecuária Municipal 2017. Prod. Pec. munic. 45:1-8.
IBGE (2017b). Panorama dos municípios. [https://cidades.ibge.gov.br/brasil/ba/casa-nova/ panorama] Acessed 17 março 2019.

Kai Z, Woan TS, Jie L, Goodale E, Kitajima K, Bagchi R, Harrison RD (2014). Shifting baselines on a tropical forest frontier: extirpations drive declines in local ecological knowledge. Plos One 9(1): e86598. [https:// doi.org/10.1371/journal.pone.0092931].

Kellert SR (1985). Attitude Toward Animals: Age-Related Development Among Children. In: M.W. Fox \& L.D. Mickley (Eds), Advances In Animal Welfare Science 1984/85 (Pp 43-60), Washington, DC: The Humane Society Of The United States.

Leal IR, Lopes AV, Machado IC, Tabarelli M (2018). Interações planta-animal na Caatinga: visão geral e perspectivas futuras. Ciência e Cultura 70(4): 35-40.

Leal LC, Andersen NA, Leal IR (2011). Anthropogenic disturbance reduces seeddispersal services for myrmecochorous plants in the Brazilian Caatinga. Oecologia 174:173-171.

Leotti VB, Coster R, Riboldi J (2012). Normalidade de variáveis: métodos de verificação e comparação de alguns testes não-paramétricos por simulação. Revista HCPA 32(2): 227-234.

Licarião MR, Bezerra DMM, Alves RRN (2013). Wild birds as pets in Campina Grande, Paraíba State, Brazil: an ethnozoological approach. Anais da Academia Brasileira de Ciências 85(1): 201-213.

Machado IC, Lopes AV (2004). Floral traits and pollination systems in the Caatinga, a Brazilian tropical dry forest. Annals of Botany 94: 365-376.

Mazerolle MJ (2004). Appendix 1: Making sense out of Akaike's Information Criterion (AIC): its use and interpretation in model selection and inference from ecological data. Mouvements et reproduction des amphibiens en tourbières perturbées 174-190.

Mourão JS, Nordi N (2006). Pescadores, peces, espacio y tiempo: un abordaje etnoecológico. Interciencia 31(5): 358-363.

Musila S, Prokop P, Gichuki N (2018). Knowledge and Perceptions of, and Attitudes to, Bats by People Living around ArabukoSokoke Forest, Malindi-Kenya. Anthrozoos 31 (2): 247-262. 
Nascimento CAR, Czaban RE, Alves RRN (2015). Trends in illegal trade of wild birds in Amazonas state, Brazil. Tropical Conservation Science 8(4): 1098-1113.

O'brien RM (2007). A caution regarding rules of thumb for variance inflation factors. Quality quantity 41(5): 673-690.

Oliveira ES (2011). Uso e conservação da fauna por populações humanas no Rio Grande do Norte, Nordeste do Brasil. Dissertação de Mestrado. Universidade Federal do Rio Grande do Norte, Natal, Br.

Oliveira WSL, Faria SL, Alves RRN (2018). Understanding the motivations for keeping wild birds in the semi-arid region of Brazil. Journal of ethnobiology and ethnomedicine 14(1): 41 doi: 10.1186/s13002-018-0243-6.

Pam G, Zeitlyn D, Gosler A (2018). EthnoOrnithology of the Mushere of Nigeria. Ethnobiology Letters 9(2): 48-64.

Quinlan MB, Quinlan RJ (2007). Modernization and medicinal plant knowledge in a Caribbean horticultural village. Medical Anthropology Quarterly 21: 169-192.

Pergams OR, Zaradic PA (2006). Is love of nature in the US becoming love of electronic media? 16- year downtrend in national park visits explained bywatching movies, playing video games, internet use, and oil prices. J Environ Manage 80:387-93.

Piacentini VQ, Aleixo A, Agne CE, Maurício GN, Pacheco JF, Bravo GA, Brito GRR, Naka LN, Olmos F, Posso S, Silveira LF, Betini GS, Carrano E, Franz I, Lees AC, Lima LM, Pioli D, Schunck F, Amaral FR, Bencke GA, Cohn-Haft M, Figueiredo LFA, Straube FC, Cesari E (2015). Lista comentada das aves do Brasil pelo Comitê Brasileiro de Registros Ornitológicos. Rev. Bras. Ornitol. 23: 91-298.

Pires-Santos D, Galvagne Loss AT, Andrea MV, Costa Neto EM (2015). O conhecimento etnoornitológico dos moradores do Município de Elísio Medrado, Bahia, Brasil. Revista Ouricuri 5: 67-85.

PNUD, IPEA, FJP (2013). Atlas do desenvolvimento humano no Brasil. [http:// www.atlasbrasil.org.br/2013/pt/consulta/] Accessed em 17 march 2019.
Provete DB, Silva FR, Souza TG (2011). Estatística aplicada à ecologia usando o R. Material didático, Universidade Estadual Paulista, São José do Rio Preto, Br [https:// cran.r-project.org/doc/contrib/Provete-

Estatistica_aplicada.pdf].

Quesada M, Rosas F, Aguilar R, Ashworth L, Rosas-Guerrero VM, Sayago R, SánchezMontoya G (2011). Human impacts on pollination, reproduction and breeding systems in tropical forest plants. In: Dirzo R, Young HS, Mooney HA, Ceballos G (eds.) Seasonally dry tropical forests: Ecology and conservation. Island Press, London, pp. 173-194.

R Core Team (2018). R: A language and environment for statistical computing. $R$ Foundation for Statistical Computing, Vienna, Austria.

Rocha JM, Santana A, Santos AE, Sales JKJ, Santos JD, Cruz Filho J, Oliveira LB, Pinheiro SA, Santana TM, Britto YP (2017). Educação Ambiental No Combate Ao Comércio llegal Da Avifauna Silvestre em Sergipe. Ethnoscientia doi: 10.22276/ethnoscientia.v2i1.48.

Santos IB, Costa-Neto EM (2007). Estudo etnoornitológico em uma região do SemiÁrido do estado da Bahia, Brasil. Sitientibus Série Ciências Biológicas 7(3): 273-288.

Sarkar D (2008). Lattice: Multivariate Data Visualization with R. Springer, New York. ISBN 978-0-387-75968-5.

Schmidt CMC (2003). Modelo de regressão de Poisson aplicado à área da saúde. ljúi,. $98 \mathrm{f}$. Dissertação de Mestrado, Universidade Regional do Noroeste do Estado do Rio Grande do Sul, $\mathrm{Br}$.

Silva JMC, Barbosa LCF, Leal IR, Tabarelli M (2017). The Caatinga: understanding the challenges. In: Silva JMC, Leal IR, Tabarelli M (eds.) Caatinga. The largest tropical dry forest region in South America. Springer International Publishing, pp. 3-19.

Soares VMS, Soares LHK, Lucena PRF, Barbosa RR (2018a). Knowledge, Food Use and Conservation of Cinegetic Avifauna: Case Study In Patos Municipality, Paraiba, Brasil. Interciencia 43(7): 491-497.

Soares VMS, Soares LHK, Lucena PRF (2018b). Local Knowledge, Use, And Conservation of Wild Birds In The Semi-Arid Region Of Paraíba State, Northeastern Brazil. Journal of Ethnobiology and Ethnomedicine 14: 77 doi: 10.1186/s13002-018-0276-x. 
Soga M, Gaston KJ (2016). Extinction of experience: the loss of human-nature interactions. Frontiers in Ecology and the Environment 14(2): 94-101.

Sobrinho MS, Tabarelli M, Machado IC, Sfair JC, Bruna EM, Lopes AV (2016). Land use, fallow period and the recovery of a Caatinga forest. Biotropica 48:586-597.

Stotz DF, Fitzpatrick JW, Parker TA, Moskovits DK (1996). Neotropical birds: ecology and conservation. the University of Chicago Press, Chicago.

Swamy V, Pinedo-Vasquez M (2014). Bushmeat harvest in tropical forests: Knowledge base, gaps and research priorities. CIFOR, Bogor, Indonesia.

Tadano SY, Ugaya CML, Franco AT (2009). Método de regressão de Poisson: metodologia para avaliação do impacto da poluição atmosférica na saúde populacional. Ambiente \& Sociedade 12(2): 241-255.

Teixeira PHR, Nascimento TT, Ferreira JMR, Azevedo SM, Telino-Junior WR, Lyra-Neves RM (2014). Local knowledge and exploitation of the avian fauna by a rural community in the semi-arid zone of northeastern Brazil. Journal of Ethnobiology and Ethnomedicine 10:81 doi: 10.1186/1746-4269-10-81.

Toledo V (2005). Ethnoecology of the Yucatec Maya: symbolism, knowledge and management of natural resources. Journal of Latin American Geography (JLAG) 4(1): 9-41.
Toledo VMM, Barrera-Bassols NA (2009). Etnoecologia: uma ciência pós-normal que estuda as sabedorias tradicionais. Desenvolvimento e Meio Ambiente 20: 31-45.

Tucker B (2007). Applying behavioral ecology and behavioral economics to conservation and development planning: An example from the Mikea Forest, Madagascar. Human Nature 18 (3): 190-208.

Turkman MAA, Silva GL (2000). Modelos Lineares Generalizados: da teoria à prática. Universidade de Lisboa, Lisboa.

Vargas-Tovar N (2000). Coevolucion del Sistema Cultural, Legal y Económico alrededor de La Caceria en un Sector de La Zona Andina, Santander Colômbia. Dissertação de Mestrado, Universidade Javeriana Pontificia, Colômbia.

Venables WN, Ripley BD (2002). Modern Applied Statistics with S. Fourth Edition. Springer, New York.

Whelan CJ, Wenny DJ, Marquis RJ (2008). Ecosystem Services Provided by Birds Ann. N.Y. Acad. Sci. doi: 10.1196/annals.1439.003.

Wickham H (2016). Ggplot2: Elegant Graphics for Data Analysis. Springer-Verlag, New York.
Received: 15 July 2019

Accepted: 02 April 2020

Published: 11 May 2020 